\title{
Retrofuturismo, espaço e corpo-mídia: steampunk e a memória do futuro'
}

\section{Retrofuturism, space and media-body: steampunk and tomorrow's memory}

\author{
Mônica Rebecca Ferrari Nunes \\ Escola Superior de Propaganda e Marketing - SP \\ <monicarfnunes@espm.br>
}

\author{
Marco Antônio Bin \\ FIAM-FAAM Centro Universitário \\ <marcobin@gmail.com>
}

\section{Como citar este artigo (How to cite this article): \\ NUNES, Mônica Rebecca Ferrari; BIN, Marco Antônio. Retrofuturismo, espaço e corpo-mídia: steampunk e a memória do futuro. Revista Famecos, Porto Alegre, v. 25, n. 2, p. 1-21, maio, junho, julho e agosto de 2018: ID29017. DOI: http://dx.doi.org/10.15448/1980-3729.2018.2.29017.}

\section{RESUMO}

Resultado parcial de pesquisa desenvolvida com apoio do CNPq, este artigo problematiza a constituição da cena steampunk; tem como objetivo descrever e analisar esta cena e suas teatralidades, atentando às conexões entre a ambiência espaciotemporal, o corpo-mídia dos jovens steamers e a produção da memória. Observa-se que a cena steampunk é ainda pouco estudada na área da Comunicação, considerando a problematização e os objetivos propostos. Com base em autores da Teoria Semiótica de Tártu-Moscou, como luri Lotman, em pensadores vinculados a estudos sobre a memória, tais como: Maurice Halbwachs, Paul Ricoeur, Andreas Huyssen e Mary Carruthers - e também em pesquisa etnográfica realizada nos festivais Anime Festival Winter, em Belo Horizonte/MG, e Steamcom, em Paranapiacaba/SP espera-se demonstrar que a memória gerada se revela como memória do futuro tendo em vista a dimensão inventiva do retrofuturismo.

Palavras-chave: Retrofuturismo. Steampunk. Memória do Futuro.

\section{ABSTRACT}

This paper presents the partial results of a study supported by CNPq. It problematizes the steampunk scene constitution; it aims to describe and analyze this scene and its theatricalities, observing the connections of the spatial-temporal ambience, the body-media of young steamers and the memory production. The steampunk scene has been little studied in Communications with this problematization and proposed objectives. Based on authors of the TartuMoscow Semiotic Theory, as luri Lotman, on thinkers of memory-related studies as Maurice Halbwachs, Paul Ricoeur, Andreas Huyssen and Mary Carruthers - and in an ethnographic research carried out in the events Anime Festival Winter, in Belo Horizonte/ $M G$, and Steamcom, in Paranapiacaba/SP - it aims to demonstrate that the memory arising from these groups, comes out as tomorrow's memory, considering the creative dimension of the retrofuturism.

Keywords: Retrofuturism. Steampunk. Tomorrow's memory.

1 Versão revista e modificada de trabalho apresentado ao Grupo de Trabalho Memória nas Mídias do XXVI Encontro Anual da Compós, Faculdade Cásper Líbero, São Paulo - SP, 6 a 9 de junho de 2017. 


\section{Introdução}

Gênero de ficção científica, nascido ao final dos anos 1980, o steampunk é inspirado na literatura do século XIX, especialmente nas aventuras de Júlio Verne (1970 a, b, c) e H.G.A Wells (1981), entre outros autores do período. É o estadunidense Kevin Wayne Jeter quem escreve duas obras que configuram o novo gênero: Morlock Night, em 1979, e Infernal Devices, em 1987, por sua vez criando viajantes do tempo, máquinas poderosas capazes de voltar ao século XIX para inúmeras aventuras. O próprio Jeter batiza os trabalhos literários seguindo tais temáticas com o termo steampunk (2017)²; sorte de literatura que traz elementos vitorianos e os de um futuro imaginado como fruto do desenvolvimento tecnológico cuja base é o vapor, steam, em inglês, de onde o nome do movimento. Já a terminologia punk, rebelde, em português, diz respeito às narrativas cyberpunks em voga na época, igualmente um gênero literário voltado ao um futuro próximo dominado pelas junções homemmáquina em uma sociedade arrasada, distópica (Amaral, 2006), o que não acontece exatamente com as narrativas steams.

Dos anos 1980 para cá, o steampunk se descolou das páginas dos livros e se expandiu para as películas cinematográficas, animes, mangás, videojogos, etc. Além das linguagens eletroeletrônicas e midiáticas, o gênero é vivido e consumido como estilo, por meio de roupas customizadas e/ou criadas pelos próprios steamers. Os jovens inventam personagens que revivem o período vitoriano por meio de indumentos hibridizados com peças novas feitas para parecerem envelhecidas: inúmeros artefatos pintados de tinta cobre que simultaneamente indiciam o tempo passado vitoriano e o futuro tecnológico. A tônica deste gênero de ficção científica e estilo é representar, por meio de suas linguagens, um mundo imaginado a partir das máquinas a vapor. Mundo paralelo cujo tempo se codifica como retrofuturo (Bublex; During, 2014), conceito a ser deslindado no decorrer deste artigo. Os steamers se reúnem nas redes sociais e presencialmente para compartilhar suas preferências culturais em festivais de cultura pop, como o Anime Friends, Anime Festival, ou em convenções específicas do grupo, como a SteamCom.

Nesses espaços, encontram amigos, inventam e performam narrativas retrofuturistas, compram mercadorias características. Organizam-se por Conselhos, como o Conselho Steampunk de São Paulo ou de Minas Gerais, encontrados com a pesquisa. Presentes em muitas capitais do país, os Conselhos ligam-se às Lojas, como uma referência às Lojas Maçônicas, mesmo não seguindo

2 Informações disponíveis em: http://sp.steampunk.com.br/2008/10/10/seguindo-o-rastro-de-vapor2\%C2\%B0-parte. 
os preceitos maçons, talvez considerando o caráter de ajuda mútua entre seus membros (Pegoraro, 2016).

No presente trabalho, o steampunk é compreendido como prática cultural e de consumo, ainda, como texto de cultura, capaz de condensar e gerar memórias, no sentido da Teoria Semiótica de Tártu Moscou (Lotman, 1990, 1996, 1999), e como cena de onde emergem teatralidades.

Partimos da ideia de Will Straw ao se referir a cenas como uma esfera circunscrita de sociabilidade, criatividade e conexão que toma forma em face de certos tipos de objetos culturais no transcurso da vida social destes objetos (Straw, 2004). Podemos ainda considerar a cena como uma espécie de teatralidade pública (Blum, 2003) exercitada nas culturas urbanas. Josette Féral (1988), pesquisadora de linguagens teatrais, e o historiador e estudioso da performance, Paul Zumthor (1997), auxiliam-nos a compreender a teatralidade no domínio das cenas estudadas.

Brevemente, podemos dizer que Féral a concebe como processo além do teatro: produção do olhar, olhar que postula e cria um espaço outro, que se torna espaço do outro e dá lugar à alteridade dos sujeitos e à emergência da ficção. Pensando com a autora, entendemos que "a teatralidade aparece como operação cognitiva (...) é um ato performativo daquele que olha ou daquele que faz (...) Ela não é um dado empírico. Ela é uma colocação do sujeito em relação ao mundo e em relação a seu imaginário" (Féral, 1988, p. 351). Zumthor (1997), por sua vez, afirma que a ação do corpo em presença põe em movimento gesto, voz, cenários, espacialidades, temporalidades e faz da performance jogo poético, em suas palavras, uma teatralidade. O jogo poético instalado soma-se ao jogo do olhar que cliva o cotidiano para a emergência da ficção, as teatralidades, instaurando, na urbe, estesias e novas experimentações do corpo, do tempo, do espaço e da memória.

No tocante à problemática da memória, fundamentamos nossas reflexões em pressupostos teóricos e metodológicos vindos da Semiótica da Cultura de Tártu-Moscou, pelo viés dos conceitos desenvolvidos por luri Lotman (1990, 1996, 1999) que considera a cultura como memória não hereditária, uma inteligência coletiva; espaço de certa memória comum em que certos textos comuns podem ser conservados e atualizados em uma dinâmica que comporta primeiramente a presença de alguns textos constantes e, em segundo lugar, a unidade dos códigos, sua invariância, mas também suas transformações. A cultura para a Escola de Tártu-Moscou é tecida por complexos sistemas de traduções sígnicas que realizam a memória, jamais una, mas internamente variada. 
Valorizamos igualmente as matrizes sociais, filosóficas e literárias dos estudos sobre a memória, como os trabalhos de Maurice Halbwachs (1990), Willi Bolle (1994), Paul Ricoeur (2007), Andreas Huyssen (2014) e Mary Carruthers (2011), de modo que, para nós, a memória é processo comunicativo, sociocultural e igualmente afetivo (Nunes, 2001).

Este artigo, resultado parcial de pesquisa mais abrangente, ${ }^{3}$ problematiza a constituição da cena steampunk; tem como objetivo descrever e analisar esta cena e suas teatralidades, atentando às conexões entre a ambiência espaciotemporal, o corpo-mídia (Baitello, 2010) dos jovens steamers e a produção da memória. Para tanto, além da pesquisa bibliográfica, o trabalho contou com etnografias ocorridas nas seguintes convenções: Steamcom, em Paranapiacaba, distrito do município de Santo André, São Paulo, edições de agosto 2015 e 2016; Anime Festival Winter, agosto 2015, em Belo Horizonte, onde pudemos entrevistar o grupo da Loja Minas Gerais do Conselho Steampunk.

As entrevistas foram obtidas por meio da metodologia da flânerie proposta por Peter McLaren (2000) ${ }^{4}$ que sugere o etnógrafo contemporâneo como um flâneur a se perder pela cidade e pelas mercadorias em busca de fragmentos narrativos que possam revelar sentidos. Em nossos trabalhos, a flânerie se traduziu em um roteiro vazado permitindo capturas regulares e singulares em torno de relatos tomados ao sabor do encontro sensório com fantasias e performances. Foram 22 depoimentos gravados; alguns registros aparecem transcritos sem obedecer à ordem cronológica de nossas visitas aos eventos. Esclarecemos que embora possamos, vez ou outra, mencionar os relatos coletados em Belo Horizonte, no sentido de trazer as características dos steamers, são os espaços/ lugares ${ }^{5}$ da vila de Paranapiacaba o recorte metodológico observado.

3 Resultado parcial da pesquisa Comunicação, consumo e memória: da cena cosplay a outras teatralidades juvenis desenvolvida com apoio do CNPq (Chamada Ciências Humanas, Sociais, Sociais Aplicadas - MCTI/CNPq/MEC/CAPES n. 22/2014). Realizada entre dezembro de 2014 e dezembro de 2016, a pesquisa ocorreu nas cidades de São Paulo, Santo André, Rio de Janeiro, Belo Horizonte e Lincoln, UK, investigando, por meio de trabalho de campo e bibliográfico, as cenas cosplay - em que jovens se vestem como personagens midiáticos, performando suas ações; a cena steampunk, apresentada parcialmente neste paper, e a medievalista, em que seus praticantes também podem se caracterizar como medievais, formar grupos de combates, realizar festas e banquetes. O resultado final está publicado em (Nunes, 2017).

4 Esta metodologia vem sendo sistematicamente utilizada nos trabalhos de campo com as cenas e teatralidades estudadas. Nas obras de nossa autoria, estes pressupostos estão explicitados com mais densidade (Nunes, 2015a; Nunes 2015; Bin, 2015).

5 A discussão conceitual sobre as distinções entre espaço e lugar não se esgotou, como salienta Santaella (2010). Acatamos a definição de Michel de Certeau (1994) e Doreen Massey (2000) que conferem ao espaço assim como ao lugar o estatuto de produtos de práticas sociais. Utilizamos os dois termos nesta acepção e de modo indistinto. 
Iniciamos o artigo apresentando as dimensões históricas desta vila e o conceito de retrofuturismo. A seguir, refletimos sobre o espaço/lugar, o corpomídia e como operam as memórias produzidas pelo grupo. A última parte traz nosso entendimento sobre a memória do futuro. Vale ressaltar que a cena steampunk é ainda pouco estudada na área da Comunicação, considerando especialmente a problematização e os objetivos propostos aqui.

\section{De Paranapiacaba ao retrofuturismo}

Em um fim de semana de cada ano, normalmente no mês de setembro, a pequena vila ferroviária de Paranapiacaba abandona seu ar pacato em meio à Mata Atlântica e ao nevoeiro que a recobre a cada tarde para se dissolver nas manhãs seguintes. Sua arquitetura relativamente bem conservada à base de pinho-de-riga acolhe famílias com crianças e principalmente jovens vindos dos mais diversos cantos do Brasil, transformando-se em um grande palco urbano onde se representam os inúmeros atos que compõem a teatralidade steampunk, muitas vezes travestida por personagens vitorianos, góticos, do velho oeste norte-americano e até do sertão brasileiro.

Segundo Rebecca Onion (2008, p. 138 - 139). "[...] os steampunks buscam menos recriar tecnologias específicas do presente momento do que reacessar o que veem como o valor afetivo do mundo material do século XIX". Ela fala do fetiche dos steamers pelos materiais como engrenagens, molas, movimento hidráulico, do prazer que sentem pelas nuvens de vapor emanados pela tecnologia da época, mobilizando-se em torno da tecnologia do vapor "como uma prática de contracultura altamente libertadora" (Onion, 2008, p. 139). Na mesma linha de interpretação, Raul Cândido de Souza, fã e integrante do Conselho Steampunk de São Paulo define assim o movimento:

[para mim] steampunk é um 'vapor marginal'; tem o charme vitoriano, característica do vapor steam, mas ele é marginal do ponto de vista criativo, porque quando você pensa em steampunk, você pensa em criação tecnológica, você pensa em possibilidades. O século XIX, assim como os tempos modernos, é repleto de preconceitos, de fato saímos do século XIX arrastando diversos preconceitos e temos uma tecnologia mais avançada. (...) Vapor marginal é uma ótima definição porque no steampunk você observa as pessoas com óculos de proteção [o indefectível google], elas estão sempre modificando coisas para uso próprio ou inventando coisas o tempo todo. Você vê a roupa vitoriana das mulheres onde tem o espartilho, que é um símbolo da opressão estética feminina, é um símbolo do sexismo, no entanto o espartilho do lado de fora da roupa e a saia um pouco mais curta [torna-se] um símbolo da liberação sexual feminina. Vapor 
marginal é a melhor definição para isso, as inúmeras possibilidades e o nosso pensamento em relação a nossa própria evolução (Souza, 2016).

Os steamers apreciam montar seus visuais, muitas vezes confeccionando artefatos ou adaptando-os das teatralidades cosplays ou do estilo vitoriano. Demonstram o olhar afetivo com materialidades do século XIX como Onion relata, e mais além, o afeto pela recriação e manuseio das indumentárias que remontam ao período, e com elas participar dos eventos. Ali, em alguns estandes expositivos, temos a presença de objetos reciclados e reinventados, que remetem igualmente ao espírito engenhoso do século XIX. A autora também fala do fascínio pelas "nuvens de vapor" como resultado do movimento das máquinas, enquanto Souza refere-se ao vapor como símbolo da prática steampunk, mas a define de modo conciso como "vapor marginal" por seu apelo criador, tecnológico, que pode levar a inúmeros mundos possíveis.

Retornamosà Paranapiacaba. A proposta decadavisitante, principalmente os praticantes da cultura, é se apresentar caracterizados por um visual steampunk, normalmente inspirados por algum personagem midiático, seja de uma obra literária, cinematográfica, de quadrinhos, e circular pelas construções que compõem o espaço urbano produzido pela empresa inglesa São Paulo Railway, a essa época ocupado por seus trabalhadores. Para os fãs, frequentar as convenções é uma oportunidade de interagir com outros visitantes em um espaço histórico constituído por máquinas e engrenagens e desfrutar o desfile de recriações retrôs, a reproduzir os estilos de um tempo que coincide mais ou menos com o auge da vila ferroviária, fins do século XIX e princípios do século XX. Incorporam, conforme diz Octavio Paz, um tempo mítico onde reelaboram ou representam heróis, com base nas histórias daquele período, ou do contemporâneo, como a Liga dos Cavalheiros Extraordinários (2003) ou Guerra nas Estrelas, de George Lucas (1977). Um tempo definido pelo prazer do gozo intenso, diferenciado, que rompe com o tempo cronológico e previsível de cada dia, e pelo encontro com outros sonhadores. Dessa forma, "o mito - disfarçado, oculto, escondido - reaparece em quase todos os atos da nossa vida e intervém decisivamente na nossa história: abre para nós as portas da comunhão" ( $\mathrm{Paz}$, 2006, p. 190). Significa dizer, o ritual ali vivenciado e compartilhado rompe uma fissura na linguagem racional do nosso tempo, possibilitando a comunhão em torno do imaginário lúdico, de um escape criativo em um tempo de alienação, em que prevalece o trabalho e a produção. Daí a experiência da teatralidade (Féral, 1988) que irrompe no cotidiano tornando possível a emergência da ficção. 
Para chegar à vila operária, onde acontece o SteamCom, os visitantes cruzam o antigo pátio ferroviário, tomado por composições de antigos vagões de trem oxidados pela intempérie, fruto de longo abandono, testemunhas de um tempo histórico em que se produziu muita riqueza e a ascensão social dos grandes monocultores paulistas, denominados de barões do café. Com a expansão da cultura cafeeira pelos derrames basálticos do centro-oeste do Estado, os ramais ferroviários cumpriram um papel fundamental: o escoamento em escala para o porto de Santos, cujo entroncamento se dava no alto da serra do Mar, em Paranapiacaba. De acordo com o estudo de Thaís Cruz sobre a formação da vila ferroviária, "a safra de 1906/07 [no Estado de São Paulo] chegou a mais de 20 milhões de sacas" (Cruz, 2007, p. 35) que locomotivas e vagões transportaram até o porto de Santos, passando por ali. Com os excedentes da produção adquiridos pelo governo com financiamento externo, e os preços em alta até pouco antes da Primeira Guerra, os barões do café realizaram sua acumulação de capital, aceleraram o funcionamento das máquinas, intensificaram o trabalho e aprofundaram a exploração de sua mão de obra, no início escrava e mais tarde imigrante.

O imaginário lúdico presente nas teatralidades steampunks tende a não contemplar o processo histórico da formação de Paranapiacaba: os trabalhadores escravos, que em grande medida plantavam o ouro negro que escoava por aqueles trilhos, foram excluídos da representação steampunk por não possuírem nem visibilidade histórica, nem ficcional. Jacob Gorender (2016) afirma que as condições para a incorporação da mão de obra negra no mercado de trabalho eram desfavoráveis em relação à crescente mão de obra imigrante europeia e mais tarde, japonesa. Os negros foram excluídos das lavouras de café após dez ou quinze anos após a Abolição, isto é, até o final do século XIX, quando se transferiram para o vale do Paraíba, ou se agregaram a outros negros em situação de subemprego ou de marginalidade na cidade de São Paulo. Ainda segundo o autor, com as fugas em massa dos escravos,

houve uma perda definitiva, mas certo número de libertos
continuou a trabalhar no café, em geral empregando-se com um
novo fazendeiro, [porém] no decênio seguinte à Abolição, os negros
seriam praticamente afastados das fazendas do Oeste de São Paulo
(Gorender, 2016, p. 217).

O que observamos nos encontros steamers de hoje é a pujança das máquinas, das engrenagens e das riquezas advindas - o fausto de um tempo transformador - a inspirar o consumo de artefatos relacionados a referenciais simbólicos de uma burguesia vitoriana europeia ou de aventureiros empoeirados 
do velho oeste estadunidense, sem a necessária correlação com os personagens alinhados ao processo histórico que gerou a vila, desde o longínquo universo dos barracões nas fazendas de café da depressão periférica paulista, aos operários já assalariados, vinculados à construção da própria vila ferroviária.

Mas ainda assim, a vila de Paranapiacaba reúne uma arquitetura e uma tipologia residencial que nos remete aos costumes e distinções sociais de uma época, o que é suficiente para desdobrar-se em seu espaço a teatralidade steamer. Para Maurice Halbwachs,

a imagem das coisas participa da inércia destas; não é o indivíduo isolado, é o indivíduo como membro do grupo, é o próprio grupo que, dessa maneira, permanece submetido à influência material e participa de seu equilíbrio (Halbwachs, 1990, p. 133).

A realização do SteamCon, que se multiplica nos ambientes, expondo a artesania dos fãs na elaboração das vestimentas, as histórias ficcionais publicadas em livros, as feirinhas com artefatos retrofuturistas, está em perfeita comunhão com as pedras da cidade, cujos traços de época reforçam a familiaridade com o período vitoriano. $O$ resto fica por conta do imaginário, das representações do corpo nos desfiles, pelos calçamentos de paralelepípedos, onde os mais diversos personagens se congraçam e se divertem. Ao tratar sobre a memória coletiva relacionada ao espaço, Halbwachs discute a relação do grupo social, os hábitos de pertença dos moradores e sua ligação afetiva com o imobiliário. Podemos aqui associar a vila de Paranapiacaba e suas características de época com os praticantes do steampunk, que mesmo não constituindo vínculos permanentes com o lugar, formam uma comunidade virtual que não se define por uma territorialidade expressa, mas conectada pelas redes digitais. Neste sentido, os encontros em Paranapiacaba não são ao acaso, a cidade e os corpos definem a concretude da cultura steamer, midiática em sua gênese, em suas mais diversas teatralizações.

Compreendemos os vínculos dessa correspondência nas relações simbólicas estabelecidas entre as práticas dos fãs com a vila ferroviária. $\mathrm{O}$ cenário real abre espaço para uma ambiência recriada. Provenientes de todas as partes do Brasil, o encontro com a carne das pedras do século XIX recompõe a cumplicidade aprazível com inúmeras possibilidades imaginativas que ligam o passado com o futuro naquilo que constitui a ideia retrofuturista.

Neste sentido, é oportuno compreender o conceito, tão presente nas práticas dos fãs do steampunk. Segundo Henry Jenkins, retrofuturismo definese como "um gênero em que permite as pessoas olharem para trás, examinando mitos e fantasias mais antigos contra a realidade contemporânea" (Jenkins, 
2007) ${ }^{6}$. Alain Bublex e Elie During, na obra Le Futur n'existe pas: rétrotypes (2014), não afirmam a não existência do futuro, como sugere o título, mas sua dimensão ativa, prospectiva, um futuro que possa coexistir com o passado e o presente. Nesse sentido, o retrofuturismo se mostra como um movimento que desvela um duplo efeito de perspectiva, por um lado futurismo retrô, ou seja, a exposição de um futuro obsoleto ou retrô futurizado e, por outro, a interpolação do futuro no passado, tal como a palavra de ordem na cena steampunk. Os protótipos são na verdade retrótipos, não se limitando apenas à reconstituição nostálgica de um protótipo de um passado, mas uma reinvenção consistente com base em seu potencial próprio. Poderíamos aqui considerar o jogo do nordesteam, uma representação proposta pelos participantes da Loja Minas Gerais do Conselho Steampunk, cujo contato se deu em nossa visita ao Anime Fest Winter 2015, que revive os duelos do velho oeste estadunidense com artefatos steampunks e situados no Nordeste brasileiro.

Em ambas as definições do retrofuturismo, o deslocamento temporal situa no passado um imaginário vinculado à tecnologia steam, e daí essa abertura à criação de um mundo paralelo a projetar um futuro retrô. Não é à toa a influência das obras de ficção científica de Júlio Verne, entre outros autores, ricos mananciais de inspiração das fantasias, quando pensamos nas características dos personagens notáveis das histórias, nos trajes singulares e principalmente nas invenções tecnológicas que propõe para as aventuras. São os relatos de antecipação, ou, como veem a partir de seus conhecimentos científicos, o futuro, reconfigurados hoje pelos steamers em seus propósitos retrofuturistas. Em outras palavras, a construção de um gênero, a ficção científica, "a antecipação de descobrimentos capazes de ocasionar transformações decisivas nos costumes e instrumentos humanos" (Caillois, 1970, p. 35). De Verne, temos 20.000 Léguas Submarinas (1970 a), narrativas sob o mar, em submarino; Viagem ao Centro da Terra (1970 b), a incursão nas profundezas do planeta; Viagem ao redor da Lua (1970 c) cujas circunstâncias serão confirmadas pelas expedições do programa Apollo, cem anos mais tarde: foguetes com três tripulantes, o giro gravitacional em torno da Lua, a aterrisagem nos mares do Sul; de Bradbury, as expedições espaciais condensadas nas Crônicas Marcianas (2010); de Wells, o deslocamento temporal com A Máquina do Tempo (1981). Em cada uma dessas histórias, uma proposta moral subjacente para seus concidadãos leitores, e por extensão, aos fãs steamers de hoje, que em suas representações valorizam um mundo virtuoso, com suas peças e engrenagens "colocando em cena (...) lições de modéstia, de

6 Todas as citações relacionadas a Jenkins (2007) remetem-se ao blog de sua autoria, cuja referência se encontra ao final do texto. 
bom senso, de tolerância ou simplesmente de humanidade" (Caillois, 1970, p. 37).

Ao refletir sobre o retrofuturismo, nas circunstâncias da pós-modernidade, Jenkins destaca duas considerações,

as imaginações passadas do futuro precisam ser entendidas como artefatos históricos de ideologias mais antigas sobre o progresso humano e que sua remobilização no presente pode ser usada como um meio de refletir sobre as falhas desses sonhos para se tornar realidades (Jenkins, 2007).

Tais remobilizações naturalmente apontam para recriações narrativas, possibilitando patamares para novas utopias, ou mesmo ucronias, que seriam o desdobramento de uma linha histórica conhecida que sofre modificações a partir de um ponto, oferecendo alternativas fictícias. O sabor das possibilidades inovadoras reside, a se pensar em Caillois, no paradoxo fundamental: "que se faz do universo precedente no momento em que o universo modificado toma o seu lugar?" (Caillois, 1970, p. 43).

O imaginário das narrativas que circulam pelo espaço público de Paranapiacaba mergulha em uma proliferação deficções criadasindividualmente, ou por pequenos grupos, como é o caso de Alexander Leader Boss, 41 anos, engenheiro de produção, crossover do personagem Darth Vader, que juntamente com amigos da cidade de Campinas, interior do estado de São Paulo, participa dos eventos e desenvolve episódios ficcionais com a tecnologia do vapor. No processo de criação, alguns ficam nos equipamentos, nas vestimentas, enquanto outros produzem novas histórias podendo ou não distorcer a realidade em um movimento utópico. Como diz Alexander, "a realização das narrativas se faz pela memória e pelo visual: na cabeça, nas roupas e na oralidade" (Boss, 2015).

A criatividade narrativa do grupo de Campinas também está presente nos integrantes da Loja mineira, exemplo de adaptação da história brasileira nas práticas steampunks. Glaikson Sant'Ana, 33 anos, o capitão Robin, desenvolve um projeto de representação inspirado em Lampião e seu bando. Explica a confecção das vestimentas a partir das materialidades, "o chapéu (de cangaceiro) terá no lugar das estrelas engrenagens para ambientar na cultura steampunk, e no lugar dos óculos circulares de Lampião, os googles" (Sant'Ana, 2015). Referese ao evento SteamCon, realizado em Paranapiacaba, quando aponta a extensão das referências vitorianas ou dos filmes americanos na estilização das fantasias, reforçando seu sentimento nacionalista:"valorizo bastante nossa história, temos um cenário imensamente rico para trabalhar (...) os próprios cangaceiros, se você pegar a foto e ver a forma deles, você consegue perceber que está praticamente 
pronto para o steampunk" (Sant'Ana, 2015). Podemos interpretar de sua fala o desejo não apenas de recriar os personagens do cangaço, simbolizados na figura de Lampião e seu bando, mas produzir uma narrativa ucrônica desse universo por eles modificado.

\section{Corpo-mídia, espaço e memória}

Trajes de couro, óculos goggles metalizados, armas nerfs acobreadas com ares de peças envelhecidas e tantas outras bugigangazinhas, como nos diz Nicole Santos, estudante de arquitetura da UFMG, 23 anos, membro da Loja Minas Gerais do Conselho Steampunk, inscrevem-se sobre os steamers. Ampliase o potencial midiático de seus corpos, em si mesmos, descritores e narradores do espaço e do tempo bem como dos lugares em que teatralizam aventuras ucrônicas, como explica Pedro Silva, 30 anos, que trabalha em um Banco da capital paulista, um dos steamers entrevistados no III SteamCom: "é como se o mundo tivesse evoluído da era vitoriana, só que evoluiu à base do vapor" (Silva, 2015). Max Silva, jornalista, 23 anos, seu amigo, complementa, "quase um universo paralelo dos seres humanos" (Silva, 2015).

O século XIX não é a única possibilidade para codificar o tempo steampunk já que "existem histórias que se passam em 2015, mas que são totalmente vitorianas, como se o mundo tivesse evoluído de uma maneira diferente", continua o steamer. As narrativas vividas em um futuro retroinventado partem, entretanto, do corpo que, por sua vez, produz os sentidos socioculturais do espaço e do tempo graças às materialidades e tecnicidades da era do vapor, por isso babados, couro, coisas feitas à mão, trens, engenhocas, engrenagens e molas, como dito na seção anterior.

Paul Ricoeur ao se deter sobre o espaço habitado e sua relação com a memória, faz-nos ver que a espacialidade corporal e ambiental é inerente à evocação da lembrança. Ponto de referência do lá e do acolá, do próximo ou distante, do dentro e do fora, do acima e do abaixo, e de tantas outras polaridades assimétricas, o corpo, diz o filósofo, é "esse aqui absoluto" (Ricoeur, 2007, p. 158). Na cena estudada, igualmente corpo-mídia (Baitello, 2010) superposto, inscrito, criador do espaço - aqui compreendido como "lugar praticado" (Certeau, 1994, p. 202), produto de práticas sociais - para, de um modo próprio, lembrar o século XIX e teatralizar qualquer temporalidade.

Corpo-mídia fortemente conectado ao lugar. Nesta comunhão para as convocações da memória, a feitura dos trajes transita entre o vitoriano e o futuro possível. André Calixto, 38 anos, trabalha em uma indústria de tubulação de gás e dali vêm muitas das peças para construir e habitar um caçador de 
autômatos, ${ }^{7}$ personagem que desenvolveu para as convenções steampunks. Para tanto, utiliza roupas de brechó, de lojas de fantasias, de $\mathrm{R} \$ 1,99$, armas nerfs customizadas, fusíveis de televisões antigas, fivelas, tiras de couro "para ficar uma coisa retrô", mas com efeito de futuro. Nas palavras de Alécia Cunha, steamer de Belo Horizonte, 33 anos, administradora, cuja personagem que criou e interpreta é uma jornalista aventureira: "a gente vai e volta; espirra no passado, volta, um futuro meio retrô, e fica imaginando [como seria]" (Cunha, 2015). Alexander Boss, acima mencionado, serve-se de peças eletrônicas, como o controle de carrinho remoto colado no capacete que cobre integralmente seu rosto no intercurso da entrevista. Alexander conta-nos sobre a liberdade "de inventar o que quiser do seu personagem e da sua fantasia", ainda nos explica este percurso narrativo retrofuturista ao sugerir: "tenta imaginar que o Star Wars não foi escrito para ser uma aventura no espaço, mas no velho oeste". O engenheiro, diferentemente de André, cria uma história para cada personagem que produz com seus croquis - "peças cenográficas, armas, armaduras".

Paralelepípedos justapostos nos caminhos da vila férrea, montanhas tomadas pela neblina depois das quatro da tarde, lembrando o fog londrino, o castelinho mais ao alto, símbolo do controle sobre os trabalhadores (Cruz, 2007), podem operar a memória do coletivo steampunk e contribuir para a revivescência do período, uma vez que "a memória coletiva tem seu ponto de apoio sobre as imagens espaciais" (Halbwachs, 1990, p. 138). Mesmo após demolições e transformações, sobrevivem vestígios materiais permitindo às lembranças ligadas ao solo e a sua imagem permanecerem materialmente fora dele, tornando possível que o grupo as retome.

A força sígnica desta espacialidade memorial, no caso de Paranapiacaba, chega-nos, em alguns relatos, como resposta quando inquirimos se haveria alguma nostalgia naquelas representações. Os steamers Pedro, Max e Lita Ferreira asseguram que sim. Entre risos, Lita, designer, 22 anos, prontamente assevera: "uma nostalgia do que você não viveu" (Ferreira, 2015). Max, que usa os trajes steampunks "no dia a dia", como reporta, concorda com a namorada e segue avaliando:

Nostalgia do que a gente não viveu. É bem isso mesmo que a gente sente. Quando a gente tá aqui em Paranapiacaba, especificamente, que é uma vila dos ingleses, cê tem o trem, cê tem a Maria Fumaça, cê tem essa coisa de voltar no tempo, e, se a gente já volta no tempo no nosso visual, a gente vai voltar no tempo no nosso meio, é como se

7 Os autômatos são figuras mecânicas que imitam seres humanos. Inventados no século XVIII, foram temas recorrentes na literatura fantástica do novecento (Calvino, 2004) e são citados com frequência nas criações steampunks. 
a gente tivesse vivendo aquilo que a gente imagina na nossa cabeça (Silva, 2015).

Pedro interrompe e complementa trazendo-nos a referência de outros espaços históricos oportunos para as teatralidades:

Há um mês atrás eu fui pra Petrópolis. Meu, se a gente conseguisse fazer um evento lá com aquelas construções históricas, salões, ia render muita foto, ia ficar muito divertido porque é uma cidade que você tem construções da época do Império até da República Nova, até um Sesc, que era o Antigo Hotel Cassino, com toda arquitetura, com tudo preservado. Dependendo do local, você organiza um evento que vai ser muito interessante porque não é só as pessoas à caráter, é um ambiente (Silva, 2015).

Sabemos que Halbwachs refere-se à estreita vinculação entre espaços, lugares e ações memoriais, postulando o desenvolvimento da memória em um quadro espacial, tendo em vista a duração do espaço, a matéria que insiste:

nossas impressões se sucedem, uma à outra, nada permanece em nosso espírito, e não seria possível compreender que pudéssemos recuperar o passado, se ele não se conservasse, com efeito, no meio material que o cerca (Halbwachs, 1990, p. 143).

Vale, entretanto, redizer que, diferentemente das comunidades presas a determinado lugar alimentando um desejo de fixidez e de segurança, os steamers estão em fluxos, não apenas graças à sua vinda passageira à vila, mas porque também seguem os fluxos midiáticos: da literatura ao cinema, a gama de criações se amplia a cada novo filme lançado, a cada videogame produzido, a cada narrativa steam publicada, todas fontes para suas teatralidades. Além disso, estão nas redes sociais, indicativo da impossibilidade de pensar o quadro espacial onde emerge a memória produzida pelos steampunks restrito apenas à dimensão fixa do lugar como resultado de uma história acumulada. Vimos que a história da vila, seus modos de produção e trabalho não estão incluídos nas representações dos steamers, escravos e operários não se transformam em personagens. O que evidencia o jogo político das representações da memória, entre o que se elege para ser lembrado como representação steampunk ou esquecido, ligado às materialidades postas sobre o corpo e ao espaço mutável.

Em consequência, ainda que possamos, com Halbwachs (1990) e Ricoeur (2007), pensar o espaço como instância fundamental para a evocação da memória bem como o corpo, devemos ressaltar o entendimento das questões do espaço e do lugar na esteira do pensamento de Certeau (1994), como já apontamos, e também de Dorren Massey (2000) que propõe pensar o lugar tal 
qual uma combinatória de corpos, objetos e fluxos, neste sentido, não estático. À luz das configurações globais, admite que sua especificidade "não é uma longa história acumulada e internalizada, mas o fato de que ele se constrói a partir de uma constelação particular de relações sociais, que se encontram e se entrelaçam num locus particular" (Massey, 2000, p. 184). Para a geógrafa inglesa, o lugar revela relações processuais, lugar de encontro, momentos articulados em redes de relações sociais cambiantes que se unem sim à história, mas como um lugar extrovertido, aberto para ligações mais amplas com o mundo e não ensimesmado.

Talvez, possamos nos valer do conceito de memória topográfica, em Walter Benjamin, cujo objetivo não é reconstruir os espaços pelos espaços, mas sim os pontos de referências para a captura "de experiências espirituais e sociais" (Bolle, 1994, p. 335). Para refletir sobre a memória evocada pelos espaços/lugares, produzida pelos steamers, quem sabe seja oportuno entender o quadro espacial de Halbwachs operando como a memória topográfica de Benjamin, isto é, de modo indicial. Montanhas enevoadas, paralelepípedos, trens, casas de pinho-de-riga construídas pela companhia ferroviária inglesa, mesmo subtraídas de seu contexto histórico, tornam-se "sinais topográficos" para a formação das emoções que cimentam a memória.

\section{Uma alegre nostalgia e a memória do futuro}

Voltamos ao relato de Lita, a jovem steamer, confirmando a existência de "uma nostalgia do que não se viveu" no "prazer de fazer tudo isso", referindose à experiência steampunk. Seguindo a descrição etimológica de nostalgia, conforme Huyssen (2014), deparamo-nos com o vocábulo vindo do grego nostos = lar e algos = dor; segundo as pesquisas do autor, a ver com o tempo irreversível, com a dor de um passado inacessível; saudade de outro lugar. "No desejo nostálgico, a temporalidade e a espacialidade estão necessariamente ligadas. A ruína arquitetônica é um exemplo da combinação indissolúvel de desejos espaciais e temporais que desencadeiam a nostalgia" (Huyssen, 2014, p. 91).

Ainda que nem tudo aqui seja ruína, podemos associá-la a alguns dos sinais topográficos da vila operária provocando nostalgia: "bem isso que a gente sente (...) quando a gente está aqui em Paranapiacaba (...)", recuperando parte do relato de Max.

Entretanto, se a nostalgia das ruínas, referida por Huyssen, diz respeito à dor de um passado perdido e, desta feita, promove sentimentos pesarosos como a tristeza, nas cenas analisadas, acha-se totalmente reconfigurada. Não apenas em virtude do fato de que as ruínas de Paranapiacaba geram emoções 
prazerosas, pois permitem o lugar de encontro e experimentações lúdicas, mas também porque a nostalgia steam tem como mote a invenção do futuro, como dito: o retrofuturismo pleno de possibilidades alternativas e inventivas em torno dos mundos projetados pela fantasia, as utopias; ou especulados como renovadas hipóteses do processo histórico e social, as ucronias, em que se pode ser "o que você quiser" (Ferreira, 2015).

É certo que o culto aos objetos em ruínas, detritos ou velhices restauradas, como Huyssen cauciona - a exemplo dos vagões abandonados ou dos brinquedos nerfs, binóculos e peças novas recebendo tinta cobre para parecerem enferrujados - somado à carga afetiva destinada ao retrô fazem da cena steampunk mais um sintoma do que o pensador denomina por cultura da memória. Porém, de modo instigante, a memória nesta cena não diz respeito apenas ao pretérito, ainda que não desconheçamos que ela se volte para a anterioridade, marca temporal da coisa lembrada, como tão bem enfatiza Paul Ricoeur (2007) a partir do Parva Naturalia, de Aristóteles. A frequência dos signos vitorianos sobre o corpo-mídia e no espaço nos diz que a memória é do passado, mas não só.

Trazemos, nas dimensões possíveis deste artigo, um modelo comunicativo e sociocultural de memória em que a invenção e o futuro são tão fundamentais quanto as marcas do passado, sem, contudo, trataremse de produções irreais. Marry Carruthers valendo-se dos estudos da retórica clássica e medieval, apresenta a memória medieval como máquina de memória, machina memorialis, ao mesmo tempo moinho, moendo os grãos da experiência passada, e farinha para gerar pão novo, "e também o elevador ou guindaste que todo mestre-pedreiro sábio aprendia a fazer e a usar na construção de novos materiais" (Carruthers, 2011, p. 27). A arte da memória monástica era uma arte para a mneme e não para a mimesis, o que significa uma arte do pensamento e da cogitação em que o aspecto realístico seria pouco importante. A memória não era apenas concebida como repetição, habilidade de reproduzir, mas como matriz de uma cogitação reminiscente, isto é, que mistura o que foi armazenado em um conjunto de esquemas de memória de acesso aleatório, aqui referindose ao uso das ferramentas como os tropos e as figuras, com a intenção de uso inventivo. Carruthers insiste em que a técnica mnemônica retórica era pensada como uma arte composicional, próximo do que atualmente se denomina imaginação, criatividade ou mesmo as experiências visionárias.

A pesquisadora reforça que no idioma monástico recordar é produzir uma visão mental, um ver coisas invisíveis a partir dos materiais da memória. "Lembrem-se do Paraíso", tropo fundante para A Cidade de Deus, de Agostinho, é um chamamento à ação do presente para o futuro, considerando que para 
os monges medievais, o Paraíso não era irreal. Carruthers comenta a propósito de um professor de retórica de Bolonha, Boncompagno da Signa, que em 1235 inclui em seu tratado sobre memória retórica as seções "De memoria paradisi" e "De memoria inferni" e lá apresenta como é possível recordar o futuro:

A memória, o meio pelo qual os humanos compreendem o tempo, habilita-nos a lembrar de coisas passadas, a abarcar as coisas presentes e a contemplar as coisas futuras por meio de sua semelhança com as coisas passadas (Carruthers, 2011, p. 112).

Neste contexto, a autora propõe pensarmos a cognição humana em termos de trajetos ou caminhos, e que o caminho cognitivo da composição pode ser entendido como rememorativo, envolvendo atos de recordação, operações mnemônicas e capturas de outras memórias.

Finalmente, interessa dizer que a memória concebida como processo comunicativo e sociocultural pode se valer de modelos, teorias ou usos que pressupõem a criação e a invenção no presente de uma composição dirigida ao futuro. De modo especial, as teatralidades steampunks criam esta memória composicional, feita por bricolagem de ações narrativas e peças e de todas as eras, inclusive as envelhecidas propositalmente. Em Paranapiacaba, os steamers vivem os seus encontros ambientados em espaços memoráveis. Suas composições são memórias do futuro, frutos do afeto por tecnologias passadas à luz do retrofuturismo. E se podemos reconhecer uma memória do futuro é porque também compreendemos a cultura como continuum semiótico (Lotman, 1996, 1999), em que textos e códigos permanecem, modificam-se, convivem, interagem, esbarroam-se, e, do choque, germina a novidade, o novo texto trazendo marcas dos antigos, genes textuais (Lotman, 1990) aptos a inscrever a imprevisibilidade na memória nascente.

\section{Considerações Finais}

Os estudos etnográficos relatados, realizados junto aos steamers nos eventos Anime Fest 2016 (Belo Horizonte) e SteamCon 2015 e 2016 (Paranapiacaba, Santo André, SP), permitem abordar diversos aspectos que integram as práticas steampunks, desde as questões estéticas que englobam o espaço do encontro - no caso, a vila ferroviária de Paranapiacaba, escolhida não por acaso como o palco das teatralidades dos corpos-mídias, ao retrofuturismo que mobiliza o imaginário e a memória na construção tanto das narrativas utópicas quanto das ucrônicas.

Constatamos que as experiências lúdicas dos steamers acionam um apelo patêmico indispensável para a cena steampunk, e com Halbwachs (1990), Ricoeur 
(2007) e o conceito de sinais topográficos, em Benjamin citado em Bolle (1994), situamos o espaço da teatralidade e o corpo como instâncias para a evocação da memória. Em pelo menos um momento, a nostalgia como lembrança de um tempo não vivido foi colocada de forma explícita (Ferreira, 2015) nos depoimentos; em outras situações, evidenciou-se de maneira implícita. Em cada personagem, uma referência midiática a destacar em um tempo histórico demarcado pelo século XIX, fossem as representações burguesas da Europa, os pistoleiros do velho oeste estadunidense, ou, ainda que em menor presença, personagens de nossa história, como os cangaceiros do sertão.

Nessa escolha situa-se o objetivo da prática steampunk: nos dois primeiros casos, o jogo e o entretenimento como mera diversão; no último caso, uma preocupação voltada para nossos valores culturais. Nesse sentido, a Loja de Minas Gerais faz uma opção bastante clara sobre o objeto de seus interesses lúdicos, exposto não apenas nas vestimentas do corpo-mídia, mas nos demais artefatos disponíveis para o público brincar e interagir.

Uma memória que se volta continuamente para o futuro, que arrasta (tractare, uma palavra do latim medieval para compor) outros elementos do passado. A definição do termo steampunk nos oferece as diretrizes da prática, imaginar um mundo paralelo, que teria evoluído em seu processo histórico e social exclusivamente com base na tecnologia do vapor, daí sua associação com o termo retrofuturismo, a subscrever que o futuro não é ainda, e que para advir, é necessário se fazer desde o presente, no caso, o presente steam, um futuro calcado em retrótipos, que não está à frente, mas ao nosso lado. Um futuro do presente que concorre com uma multiplicidade de futuros do passado, a despertar os estados brumosos da ficção científica, a realizar os lugares fantasiosos de nossas utopias, a simular o fluxo de nosso processo histórico e social, ao sabor das mais inventivas ucronias.

\section{REFERÊNCIAS}

AMARAL, Adriana. Visões perigosas: uma arqueologia do punk e do cyberpunk. Porto Alegre: Sulina, 2006.

BAITELLO, Norval. A serpente, a maçã e o holograma: esboços para uma Teoria da Mídia. São Paulo: Paulus, 2010.

BIN, Marco. Espaço urbano, performance e memória: a poética do corpo na poesia marginal e na cena cosplay. In: NUNES, Mônica R.F. (Org.). Cena cosplay: comunicação, consumo, memória nas culturas juvenis. Porto Alegre: Sulina, 2015. 
BOLLE, Willi. Fisiognomia da metrópole moderna: representação da História em Walter Benjamin. São Paulo: Editora da Universidade de São Paulo, 1994.

BLUM, Alan. The Imaginative Structure of the City. Montreal: McGuill-Queen's University Press, 2003.

BOSS, Alexander L. Entrevista sobre steampunk. III SteamCon, Paranapiacaba, 6 ago. 2015. Trabalho de campo referente à pesquisa Comunicação, consumo e memória: da cena cosplay a outras teatralidades juvenis. Entrevista concedida a Mônica Nunes, Marco Bin, Gilson Pedroza e Lucas Teixeira.

BRADBURY, Ray. Crônicas Marcianas. Rio de Janeiro: Globo, 2010.

BUBLEX, Alain; DURING, Elie. Le future n'existe pas: rétrotypes. Paris: Éditions B42, 2014.

CAILLOIS, Roger. Imágenes, imágenes... Buenos Aires: Editorial Sudamericana, 1970.

CALVINO, Italo (Org.). Contos fantásticos do século XIX: o fantástico visionário e o fantástico cotidiano. São Paulo: Companhia das Letras, 2004.

CALIXTO, André. Entrevista sobre steampunk. IV SteamCon, Paranapiacaba, 7 ago. 2016. Trabalho de campo referente à pesquisa Comunicação, consumo e memória: da cena cosplay a outras teatralidades juvenis. Entrevista concedida a Lucas Teixeira e Gilson Pedroza.

CARRUTHERS, Mary. A técnica do pensamento: meditação, retórica e a construção das imagens (400-1200). São Paulo: Editora da Unicamp, 2011.

CERTEAU, Michel de. A invenção do cotidiano: 1. Artes do fazer. Petrópolis: Vozes, 1994.

CUNHA, Alécia. Entrevista sobre steampunk. Anime Fest Winter, MinasCentro. Belo Horizonte, 19 set. 2015. Trabalho de campo referente à pesquisa Comunicação, consumo e memória: da cena cosplay a outras teatralidades juvenis. Entrevista concedida a Mônica Nunes, Marco Bin, Caroline Santillo e Gilson Pedroza.

CRUZ, Thaís F. dos Santos. Paranapiacaba: a arquitetura e o urbanismo de uma vila ferroviária. 2007. 195 f. Dissertação (Mestrado em Arquitetura e Urbanismo), Escola de Engenharia de São Carlos da Universidade de São Paulo, USP, 2007.

FÉRAL, Josette. La thêatralité: la spécificité du langage théatral. Poétique, Paris, septembre, p. 347- 361, 1988.

FERREIRA, Lita. Entrevista sobre steampunk. III SteamCon, Paranapiacaba, 6 ago. 2015. Trabalho de campo referente à pesquisa Comunicação, consumo e memória: da cena cosplay a outras teatralidades juvenis. Entrevista concedida a Mônica Nunes, Marco Bin, Gilson Pedroza e Lucas Teixeira. 
GORENDER, Jacob. A escravidão reabilitada. São Paulo, Expressão Popular/Fundação Perseu Abramo, 2016.

Guerra nas Estrelas. Direção: George Lucas. Produção: Gary Kurtz. Intérpretes: Mark Hamill, Harrison Ford, Carrie Fisher, Alec Guinness, Kenny Baker, Anthony Daniels, Robert Clarke, Peter Cushing, David Prowse, Peter Mayhew. Música: John Williams. Estados Unidos, 20 ${ }^{\text {th }}$ Century Fox, 1977. Cor, $121 \mathrm{~min}$.

HALBWACHS, Maurice. A memória coletiva. São Paulo: Centauro Editora, 1990.

HERSHMANN, Micael e outros. Os steampunks e as inquietações de um mundo retrofuturista. In: ENCONTRO DA COMPÓS, 2012, Juiz de Fora. Anais... Juiz de Fora: UFJF, 2012. Disponível em: http://www.compos.org.br/biblioteca.php. Acesso em: 21 mar. 2015.

HUYSSEN, Andreas. Culturas do passado-presente: modernismos, artes visuais, políticas da memória. Rio de Janeiro: Contraponto, 2014.

JENKINS, Henry. The tomorrow that never was: retrofuturism in the comics of Dean Motter. Los Angeles, 17 jun. 2007. Disponível em: http://henryjenkins. org/2007/06/the_tomorrow_that_never_was_re.html. Acesso em: 1 out. 2017.

JETER, Kevin W. Infernal devices: a mad Victorian fantasy. New York: Sta. Martin's Press, 1987.

LIGA dos Cavalheiros Extraordinários. Direção: Stephen Norrington. Produção: Trevor Albert e Don Murfy. Intérpretes: Sean Connery, Naseeruddin Shah, Peta Wilson, Stuart Townsend, Tony Curran, Shane West e Jason Flemyng. Música: Trevor Jones. Alemanha, EUA, Reino Unido, 20th Century Fox, 2003. P\&B, cor, $110 \mathrm{~min}$.

LOTMAN, luri. La semiosfera I. Madri: Ediciones Cátedra, 1996.

. Cultura y explosion. Barcelona: Gedisa, 1999.

Universe of the mind: a semiotic theory of culture. Bloomington and Indianapolis: Indiana University Press, 1990.

MASSEY, Doreen. Um sentido global do lugar. In: ARANTES, Antonio. (Org). $\mathbf{O}$ espaço da diferença. Campinas, São Paulo: Papirus, 2000. Disponivel em: http://www2. fct.unesp.br/docentes/geo/necio_turra/PPGG\%2020PESQUISA\%20QUALI\%20 PARA\%20GEOGRAFIA/DOREEN\%20MASSEY\%20\%20SENTIDO\%20GLOBAL\%20 DO\%20LUGAR.pdf. Acesso em: 15 fev. 2017.

MCLAREN, Peter. Multiculturalismo revolucionário. Porto Alegre: Artmed, 2000.

NUNES, Mônica R. F. (Org.) Cosplay, steampunk, medievalismo: memória e consumo em teatralidades juvenis. Porto Alegre: Sulina, 2017. 
Memórias e matrizes em textos midiáticos explosivos: cenas medievalistas na cultura jovem. Intexto, Porto Alegre, UFRGS, n. 37, p. 242-262, set/dez. 2016. http://dx.doi.org/10.19132/1807-8583201637.242-262.

. (Org.) Cena cosplay: comunicação, consumo e memória nas culturas juvenis. Porto Alegre: Sulina, 2015a.

Relatos de campo: a flânerie e a história oral como métodos de pesquisa em cenas lúdicas. In: MARTINO, Luis Mauro Sá; MARQUES, Angela C. Salgueiro (Orgs). Teorias da Comunicação: processos, desafios e limites. São Paulo: Plêiade, 2015.

A memória na mídia: a evolução dos memes de afeto. São Paulo: Annablume/ FAPESP, 2001.

ONION, Rebecca. Reclaiming the machine: an introductory look at steampunk. NeoVictorian Studies, v. 1, n. 1, p. 138-163, Autumn, 2008. Disponível em: http:// www.neovictorianstudies.com/past_issues/Autumn2008/NVS\%201-1\%20 R-Onion.pdf. Acesso em: 13 fev. 2017.

PAZ, Octavio. O labirinto da solidão. São Paulo: Paz e Terra, 2006.

PEGORARO, Everly. No compasso do tempo steampunk: o retrofuturismo no contexto brasileiro. Jundiaí: Paco Editorial, 2016.

RICOEUR, Paul. A memória, a história, o esquecimento. São Paulo: Editora da Unicamp, 2007.

SANT'ANA, Glaikson. Entrevista sobre steampunk. Anime Fest Winter, MinasCentro. Belo Horizonte, 19 set. 2015. Trabalho de campo referente à pesquisa Comunicação, consumo e memória: da cena cosplay a outras teatralidades juvenis. Entrevista concedida a Mônica Nunes, Marco Bin, Caroline Santillo e Gilson Pedroza.

SANTOS, Nicole. Entrevista sobre steampunk. Anime Fest Winter, MinasCentro. Belo Horizonte, 19 set. 2015. Trabalho de campo referente à pesquisa Comunicação, consumo e memória: da cena cosplay a outras teatralidades juvenis. Entrevista concedida a Mônica Nunes, Marco Bin, Caroline Sotilo e Gilson Pedroza.

SANTAELLA, Lúcia. A ecologia pluralista da comunicação. São Paulo: Global, 2010.

SILVA, Pedro. Entrevista sobre steampunk. III SteamCon, Paranapiacaba, 6 ago. 2015. Trabalho de campo referente à pesquisa Comunicação, consumo e memória: da cena cosplay a outras teatralidades juvenis. Entrevista concedida a Mônica Nunes, Marco Bin, Gilson Pedroza e Lucas Teixeira.

SILVA, Max. Entrevista sobre steampunk. III SteamCon, Paranapiacaba, 6 ago. 2015. Trabalho de campo referente à pesquisa Comunicação, consumo e memória: da cena cosplay a outras teatralidades juvenis. Entrevista concedida a Mônica Nunes, Marco Bin, Gilson Pedroza e Lucas Teixeira. 
SOUZA, Raul C. Entrevista sobre steampunk. IV SteamCon, Paranapiacaba, 7 ago. 2016. Trabalho de campo referente à pesquisa Comunicação, consumo e memória: da cena cosplay a outras teatralidades juvenis. Entrevista concedida a Gilson Pedroza e Lucas Teixeira.

STEAM PUNK. Conselho. Disponível em: http://sp.steampunk.com.br/o-movimento/. Acesso em: 13 fev. 2017.

VERNE, Júlio. 20.000 mil léguas submarinas. São Paulo: Companhia Distribuidora de Livros, 1970a.

Viagem ao centro da terra. São Paulo: Companhia Distribuidora de Livros, 1970b.

. Viagem ao redor da Lua. São Paulo: Companhia Distribuidora de Livros, 1970c.

STRAW, Will. Cultural Scenes. Loisir et Societé/Society and Leisure, v. 27, n. 2, 2004. Disponível em: http://strawresearch.mcgill.ca/straw/loisirarticle.pdf. Acesso em: 15 fev. 2017.

WELLS, H. G. A máquina do tempo. Rio de Janeiro: Ed. Francisco Alves, 1981.

ZUMTHOR, Paul. Introdução à poesia oral. São Paulo: Hucitec, 1997.

Recebido em: $1 / 11 / 2017$

Aceito em: 16/3/2018

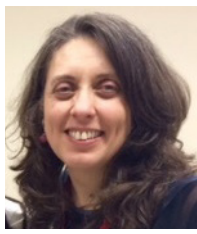

Dados dos autores:

Mônica Rebecca Ferrari Nunes | monicarfnunes@espm.br

Docente e Pesquisadora e do Programa de Pós-Graduação Stricto Sensu em Comunicação e Práticas

de Consumo, PPGCOM- ESPM, SP. Líder do MNEMON - grupo de pesquisa em Memória, Comunicação e Consumo (ESPM/CNPq).Doutora em Comunicação e Semiótica pela Pontifícia Universidade Católica de São Paulo (1998). Mestre em Comunicação e Semiótica pela Pontifícia Universidade Católica de São Paulo (1993).

Endereço da autora:

Programa de Pós-Graduação em Comunicação e Práticas de Consumo da Escola Superior de Propaganda e Marketing (ESPM-SP)

Rua Doutor Álvaro Alvim, 123

04018-010 - São Paulo (SP) - Brasil

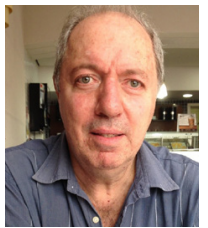

Marco Antônio Bin | marcobin@gmail.com

FIAM-FAAM Centro Universitário

Doutor em Ciências Sociais pela PUC de São Paulo, mestrado em Comunicação \& Semiótica pela mesma universidade. Bacharel em Geografia pela Faculdade de Filosofia, Letras e Ciências Humanas (FFLCH/USP). Desde agosto de 2013 atua como professor no curso de Comunicação Social da FIAM-FAAM. É membro participante do Grupo de Pesquisa em Memória, Comunicação e Consumo (MNEMON) do Programa de Pós-Graduação em Comunicação e Práticas de Consumo da ESPM, como também do Grupo de Pesquisa Textos da Cultura em Mídias Diferenciadas (TCULT) do Departamento de Jornalismo e Editoração da ECA/ USP.

Endereço do autor:

FIAM-FAAM Centro Universitário

Avenida Morumbi, 501

Morumbi - São Paulo (SP) - Brasil 